\title{
High-Flexion Posterior-Stabilized Total Knee Prosthesis: Is It Worth the Hype?
}

\author{
Sanjeev Jain, MS ${ }^{1}$, Aditya Chandrashekhar Pathak, $\mathrm{MS}^{1,2}$, Kalaivanan Kanniyan, $\mathrm{MS}^{1}$, Sourabh Kulkarni, MS ${ }^{1}$, \\ Sandeep Tawar, MBBS ${ }^{1}$, and Prashant Mane, $\mathrm{MBBS}^{1}$ \\ ${ }^{1}$ Department of Orthopaedics, Dr LH Hiranandani Hospital, Mumbai; ${ }^{2}$ Department of Orthopaedics, Dr Babasaheb Ambedkar Hospital, Byculla, India
}

High-flexion knee prosthesis was introduced with the aim of obtaining higher degree of flexion and good survivorship in patients with high functional demands or those requiring squatting, kneeling, etc., which is more common in Asians. Based on all the research and experience with this prosthesis, it was concluded that high flexion designs meet the need of deeper degrees of flexion in selected sets of patients only. Results were equal and comparable to the traditional standard posterior-stabilized total knee arthroplasty design and superior to it in terms of gaining more flexion and fulfilling activities, such as squatting, kneeling, and sitting cross-legged.

Keywords: Knee, Arthroplasty, Posterior stabilized, High flexion

\section{Why Is the High Flexion Knee Prosthesis Needed?}

In a study by Kurtz et al. ${ }^{1}$ based on the historical growth trajectory of arthroplasty surgeries, the demand for primary total hip and knee arthroplasty among patients less than 65 years old was projected to exceed $50 \%$ of the total hip and knee arthroplasty patients of all ages by 2011 and 2016, respectively. Patients less than 65 years old were projected to exceed $50 \%$ of the revision total knee arthroplasty (TKA) patient population by 2011. This study clearly stated that younger patients would undergo arthroplasty as they have higher functional demands and expectation. Higher degree of flexion is one of the major limitations of the conventional total knee arthroplasty. Certain studies have also shown reduction of flexion degree after total knee replacement ${ }^{2,3)}$.

Received May 13, 2013; Revised July 7, 2013; Accepted July 20, 2013 Correspondence to: Sanjeev Jain, MS

Department of Orthopaedics, Hiranandani Orthopaedics Medical Education, Dr LH Hiranandani Hospital, Hillside Avenue, Hiranandani Gardens, Powai, Mumbai 400-076, India

Tel: +91-22-2576-3300, Fax: +91-22-2576-3311

E-mail: drsanjain@gmail.com

This is an Open Access article distributed under the terms of the Creative Commons Attribution Non-Commercial License (http://creativecommons.org/licenses/by-nc/3.0/) which permits unrestricted non-commercial use, distribution, and reproduction in any medium, provided the original work is properly cited.
Knee flexion is one of the most important factors in performing many daily routine activities: climbing up and down the stairs require $90^{\circ}-120^{\circ}$ of flexion; going in and out of a bathtub requires $130^{\circ}-140^{\circ}$ of flexion; and kneeling, squatting, and sitting crosslegged require beyond $150^{\circ}$ of flexion ${ }^{4,5)}$. Activities like sitting cross-legged, kneeling, and squatting are an important part of daily routine activities in Asian population ${ }^{6}$. Following total knee arthroplasty, maximal flexion does not exceed $110^{\circ}-120^{\circ}$ in most of the cases ${ }^{7-9)}$.

Hence there was a need for the advent of a newer prosthesis design that would provide approximately $150^{\circ}$ of deep flexion so as to meet the demands of patients of all ages with long-term survivorship of the implant. Flexion in TKA depends on various factors, such as prosthesis design itself, preoperative flexion, gender, body mass index, any previous surgical procedures of the knee, cause of arthritis, efficacy of extensor mechanism, intraoperative positioning of implants, flexion-extension gaps (ligament balance), surgical technique, osteophyte removal, and patellofemoral joint condition ${ }^{10,11)}$.

\section{What Is the High Flexion Knee Prosthesis?}

The aim of the high flexion design is to achieve maximum flexion with high contact area and low contact stress, maintaining stability throughout the range of motion. Certain modifications

www.jksrr.org 
were made to high flexion designs of various companies to provide maximum contact area as the posterior condyles roll back to a flexion angle of up to $155^{\circ}$.

The high flexion design has a smaller femoral radius of curvature and thicker posterior condylar component. The smaller femoral radii of curvature increase the contact area between the posterior femoral condyle and the tibial insert. In addition to the thicker posterior condyle, it has a modified cam and post mechanism with increased jump distance to avoid dislocation at deep flexion angles and decrease contact stresses by increasing the contact area. An anterior cut out slope in the polyethylene insert decreases patello-femoral impingement by accommodating extensor mechanisms. These high-flexion prostheses facilitate physiological posterior femoral rollback.

The cam and spine mechanism was thickened and elongated in order to provide greater jump height in deep degrees of flexion while providing proper roll back and to prevent posterior subluxation of tibia ${ }^{12}$. However, it is not the prosthesis design alone that decides the outcome of total knee arthoplasty. Many other factors, such as proper patient selection and surgical technique, need to be taken into consideration. The best candidates for total knee arthroplasty using a high-flexion prosthesis arenon-obese, well-motivated patients with 1) high functional demands and good compliance, 2) intact collateral ligaments, 3) a deformity of less than $20^{\circ}$ in any plane, 4) a thigh-calf index of less than $90^{\circ}, 5$ ) most importantly, minimum $100^{\circ}$ of preoperative flexion range.

Standard principles of surgery are to be followed during total knee replacement with high flexion designs. Only difference in technique is that more posterior condylar bone cuts should be made and an extra bone cut is necessary to accommodate the modified cam and post mechanism.

\section{Outcomes of High Flexion Total Knee Replacement}

High flexion knee prosthesis has become popular in recent times with an expectation of getting deep degrees of flexion, more so in younger populations with high demands to return to their normal activity level ${ }^{13,14}$. Because prosthesis design itself was not the sole criteria to get deeper degrees of flexion, results of high flexion knee prosthesis were not encouraging in a few studies in contrast to our experience. High flexion knee prosthesis improves the knee range of motion compared to traditional designs by $15^{\circ}-25^{\circ}$ and also facilitates deeper bending for squatting, kneeling, and sitting cross-legged. Patient selection is the most important factor to get maximum function.

Due to the design modifications aimed at obtaining higher degrees of flexion, high flexion design requires $2-4 \mathrm{~mm}$ of additional bone resection from posterior condyles and from inter condylar notch, which may weaken the bone supporting load from the femoral component ${ }^{15)}$. This may have a significantly negative impact in the long term when revisions should be performed. Removal of excess bone posteriorly shortens the posterior radius, which could cause instability and increased tibial and patellar stresses ${ }^{16)}$. Several studies have also shown increased contact stresses during deep flexion and greater wear and early failure of the prosthesis despite design modifications ${ }^{17,18)}$. On the contrary, other studies have shown lower incidence of femoral condylar lift-off with average weight-bearing range of motion (measured using fluoroscopy) being $125^{\circ}$, which is similar to kinematic patterns of a healthy knee, thus hypothesizing that forces acting on the patella were not increased in deep flexion and that high flexion prosthesis may mimic normal knee kinematics ${ }^{7,19)}$. Few studies have also shown cam post disengagement and lateral femoral condylar lift off in deeper degree of flexion ${ }^{14}$.

Studies have shown higher incidence of femoral component loosening following total knee replacement using a high flexion prosthesis that results in early revision ${ }^{20,21)}$. However there are Level II studies that have shown good mid- to long-term survivorship of high flexion knee prosthesis without any evidence of loosening ${ }^{22,23)}$. In our experience, high flexion knee prosthesis (Fig. 1) resulted in no component loosening and good mid-term survivorship when used with a proper surgical technique inap-
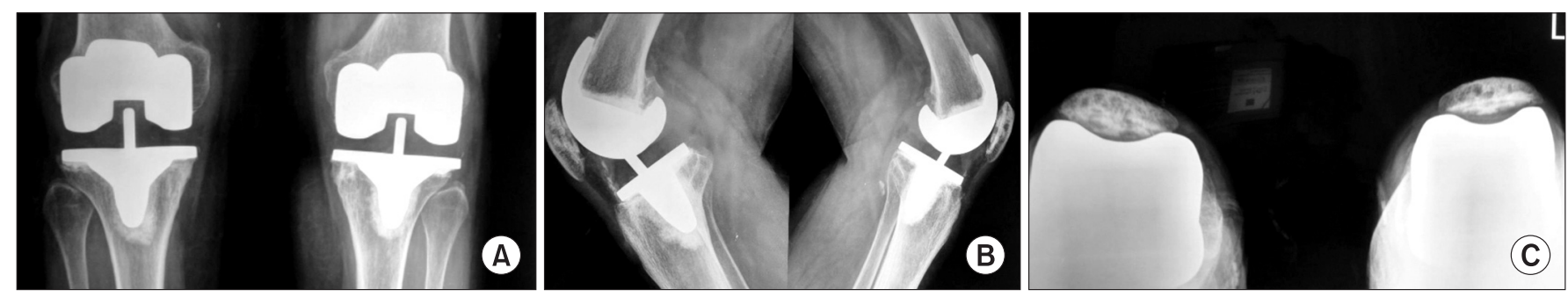

Fig. 1. Anteroposterior views (A), lateral views (B), and skyline views (C) were obtained 7 years after high flexion posterior-stabilized total knee arthroplasty. 


\section{Jain et al. High-Flexion Posterior-Stabilized TKA}

\begin{tabular}{|c|c|c|c|c|c|c|c|}
\hline No. & Author & Study & Level & No. of patients \& follow-up (mean) & Outcome (mean) & Complications & $\begin{array}{l}\text { Favor/ } \\
\text { against high } \\
\text { flex }\end{array}$ \\
\hline 1 & Mehin et al. ${ }^{29)}$ & Meta-analysis & I & - & $\begin{array}{l}\text { New generation of high-flex knee } \\
\text { prostheses do not increase the } \\
\text { postoperative maximum knee flexion } \\
\text { compared with conventional implants }\end{array}$ & - & Against \\
\hline 2 & Kim et al. ${ }^{34)}$ & $\begin{array}{l}\text { Range of motion of standard and high- } \\
\text { flexion posterior stabilized TKA }\end{array}$ & II & $\begin{array}{l}50 \text { patients undergoing bilateral TKR with } \\
\text { mean follow-up of } 2.1 \text { years }\end{array}$ & Conventional $-136^{\circ}$ vs. high flex $139^{\circ}$ & - & Against \\
\hline 3 & $\begin{array}{l}\text { McCalden } \\
\text { et al. }^{32)}\end{array}$ & $\begin{array}{l}\text { Trial comparing "high-flex" vs. "standard" } \\
\text { posterior cruciate substituting } \\
\text { polyethylene tibial inserts in TKA }\end{array}$ & II & $\begin{array}{l}50 \text { patients in each group follow-up for } 2.7 \\
\text { years }\end{array}$ & Conventional $-123^{\circ}$ vs. high flex $124^{\circ}$ & - & Against \\
\hline 4 & Nutton et al. ${ }^{35)}$ & $\begin{array}{l}\text { Functional outcome and range of flexion } \\
\text { following TKA with the NexGen } \\
\text { standard and high flexion components }\end{array}$ & I & 28 patients in each group for 1 year & Conventional $-106^{\circ}$ vs. high flex $110^{\circ}$ & - & Against \\
\hline 5 & Wohlrab et al. ${ }^{36)}$ & $\begin{array}{l}\text { Does the NexGen LPS flex mobile knee } \\
\text { prosthesis offer advantages compared } \\
\text { to the Nex Gen LPS }\end{array}$ & II & $\begin{array}{l}30 \text { patients in each group followed for } 34 \\
\text { years }\end{array}$ & Conventional $-109^{\circ}$ vs. high flex $112^{\circ}$ & - & Against \\
\hline 6 & $\begin{array}{l}\text { Weeden and } \\
\text { Schmidt }^{24}\end{array}$ & $\begin{array}{l}\text { Study of primary total knee components } \\
\text { designed for increased flexion }\end{array}$ & II & $\begin{array}{l}25 \text { patients in each group followed up for } 1 \\
\text { year }\end{array}$ & Conventional $-120^{\circ}$ vs. high flex $133^{\circ}$ & - & Favor \\
\hline 7 & Kim et al. ${ }^{22)}$ & $\begin{array}{l}\text { High-flexion total knee arthroplasty: } \\
\text { survivorship and prevalence of } \\
\text { osteolysis }\end{array}$ & II & 50 in each group followed up for 10 years & Conventional $-133^{\circ}$ vs. high flex $135^{\circ}$ & - & Against \\
\hline 8 & $\begin{array}{l}\text { Endres and } \\
\text { Wilke }^{25)}\end{array}$ & $\begin{array}{l}\text { High flexion total knee arthroplasty: mid- } \\
\text { term follow up of } 5 \text { years }\end{array}$ & IV & 79 patients evaluated over 5 years & Preoperative $-82^{\circ}$ vs. postoperative $122^{\circ}$ & $\begin{array}{l}\text { 2- DVT, } 1 \text { patient decrease ROM, } 8 \\
\text { patients with lateral tilt of the patella- } \\
\text { underwent patellar resurfacing }\end{array}$ & Favor \\
\hline 9 & $\begin{array}{c}\text { Maniar and } \\
\text { Singhi }^{23}\end{array}$ & $\begin{array}{l}\text { High-flex rotating platform knee } \\
\text { implants: two- to 6-year results }\end{array}$ & IV & 53 knees followed up for 4 years & Preoperative $-124^{\circ}$ vs. postoperative $130^{\circ}$ & $\begin{array}{l}2 \text { patient with decrease ROM- } \\
\text { manipulated in GA }\end{array}$ & Favor \\
\hline 10 & Sancheti et al. ${ }^{37)}$ & $\begin{array}{l}\text { Indus knee prosthesis, prospective, } \\
\text { multicentric trial }\end{array}$ & IV & $\begin{array}{l}276 \text { patients with average of } 2.5 \text { years of } \\
\text { follow-up }\end{array}$ & $\begin{array}{l}\text { Preoperative }-106^{\circ} \text { to postoperative } \\
132^{\circ}\end{array}$ & $\begin{array}{l}1 \text { case of periprosthetic fracture and } 1 \\
\text { case of infection }\end{array}$ & Favor \\
\hline 11 & Huang et al. ${ }^{26)}$ & $\begin{array}{l}\text { The early results of high-flex total knee } \\
\text { arthroplasty }\end{array}$ & $\begin{array}{l}\text { III } \\
\text { (matched } \\
\text { cohort) }\end{array}$ & 25 cases followed up for 2 years & Conventional $-126^{\circ}$ vs. high flex $138^{\circ}$ & $\begin{array}{l}\text { One patient in each group with anterior } \\
\text { knee pain }\end{array}$ & Favor \\
\hline 12 & Nutton et al. ${ }^{38)}$ & $\begin{array}{l}\text { Does a mobile-bearing, high- flexion } \\
\text { design increase knee flexion after total } \\
\text { knee replacement? }\end{array}$ & II & $\begin{array}{l}41 \text { patients fixed-bearing posterior } \\
\text { cruciate ligament-preserving design (FB- } \\
\text { S) was compared with that of } 36 \text { patients } \\
\text { high-flexion rotating-platform posterior } \\
\text { stabilized design (RP-F) at one year after } \\
\text { TKR }\end{array}$ & $\begin{array}{l}\text { Non-weight-bearing flexion was } 107^{\circ} \\
\text { and for the FB-S group and } 113^{\circ}\end{array}$ & - & Favor \\
\hline 13 & $\mathrm{Kim} \mathrm{et} \mathrm{al.}^{39)}$ & $\begin{array}{l}\text { The NexGen LPS-flex to the knee } \\
\text { prosthesis at a minimum of three years }\end{array}$ & IV & 259 TKRs $(98.2 \%)$ was 3.8 years & $\begin{array}{l}\text { Preoperative }-117^{\circ} \text { to postoperative } \\
135^{\circ}\end{array}$ & $\begin{array}{l}1 \text { case of periprosthetic fracture and } 1 \\
\text { case of infection }\end{array}$ & Favor \\
\hline 14 & Han et al. ${ }^{21)}$ & $\begin{array}{l}\text { High incidence of loosening of the } \\
\text { femoral component in legacy posterior } \\
\text { stabilised-flex total knee replacement }\end{array}$ & IV & 72 TKR followed up for 32 months & $\begin{array}{l}\text { Preoperative }-121^{\circ} \text { to postoperative } \\
132^{\circ} \text { at } 32 \text { months follow-up }\end{array}$ & $\begin{array}{l}27 \text { patients at follow-up of } 32 \text { months had } \\
\text { radiolucent lines femoral component of } \\
\text { which } 15 \text { patients were asymptomatic } \\
\text { and required revision }\end{array}$ & $\begin{array}{l}\text { Favor as } \\
\text { well as } \\
\text { against }\end{array}$ \\
\hline 15 & $\begin{array}{l}\text { Hepinstall } \\
\text { et al. }{ }^{40)}\end{array}$ & $\begin{array}{l}\text { High-flexion total knee replacement: } \\
\text { functional outcome at one year }\end{array}$ & IV & $\begin{array}{l}\text { ( } 100 \text { knees) were prospectively followed } \\
\text { for } 1 \text { year after TKR with a rotating- } \\
\text { platform posterior- stabilized high- } \\
\text { flexion prosthesis }\end{array}$ & $\begin{array}{l}\text { Preoperative }-111^{\circ} \text { to postoperative } \\
125^{\circ}\end{array}$ & 17 patients lost to follow-up & Favor \\
\hline 16 & Lee et al. ${ }^{41)}$ & $\begin{array}{l}\text { High-flexion prosthesis improves } \\
\text { function of TKA in Asian patients } \\
\text { without decreasing early survivorship }\end{array}$ & IV & $\begin{array}{l}698 \text { primary TKAs with follow-up of } 4.8 \\
\text { years }\end{array}$ & $\begin{array}{l}\text { Preoperative }-120^{\circ} \text { to postoperative } \\
135^{\circ}\end{array}$ & $\begin{array}{l}\text { Six of the } 698 \text { knees ( } 0.9 \% \text { ) developed } \\
\text { aseptic loosening (three femoral and } \\
\text { three tibial) }\end{array}$ & Favor \\
\hline 17 & Sumino et al. ${ }^{31)}$ & $\begin{array}{l}\text { Do high flexion posterior stabilized total } \\
\text { knee arthroplasty designs increase knee } \\
\text { flexion? }\end{array}$ & $\begin{array}{l}\text { I, meta- } \\
\text { analysis }\end{array}$ & $\begin{array}{l}\text { 2,104 PS knees that received conventional } \\
\text { implants and } 518 \text { knees that received } \\
\text { high-flextion implants }\end{array}$ & $\begin{array}{l}\text { The pooled gain in flexion was } 4.70^{\circ} \text { in } \\
\text { the conventional group }(\mathrm{p}<0.0001) \\
\text { and } 4.81^{\circ} \text { in the high flex group } \\
(\mathrm{p}=0.0008)\end{array}$ & - & Against \\
\hline 18 & Bollars et al..$^{20)}$ & $\begin{array}{l}\text { Femoral component loosening in high- } \\
\text { flexion total knee replacement }\end{array}$ & IV & In vitro study & $\begin{array}{l}\text { High-flexion designs have a greater risk } \\
\text { for femoral component loosening } \\
\text { than conventional TKR designs }\end{array}$ & - & Against \\
\hline 19 & Nam et al. ${ }^{42)}$ & $\begin{array}{l}\text { A comparison of the clinical and } \\
\text { radiographic results of press fit condylar } \\
\text { rotating- platform high- flexion and low } \\
\text { contact stress mobile bearing prosthesis } \\
\text { in TKA: short term results }\end{array}$ & II & $\begin{array}{l}16 \text { patients in high flex vs. } 19 \text { patients in } \\
\text { conventional group mean follow-up of } 3.5 \\
\text { years }\end{array}$ & $\begin{array}{l}\text { Conventional } 125^{\circ} \text { and } 126^{\circ} \text { in high } \\
\text { flex }\end{array}$ & $\begin{array}{l}1 \text { case of revision due to early loosening, } \\
2 \text { case of patella clunk syndrome }\end{array}$ & Favor \\
\hline 20 & $\begin{array}{l}\text { Argenson } \\
\text { et al. } .^{19}\end{array}$ & $\begin{array}{l}\text { A high flexion total knee arthroplasty } \\
\text { design replicates healthy knee motion }\end{array}$ & III & $\begin{array}{l}\text { Three-dimensional patello-femoral } \\
\text { kinematics were evaluated during a } \\
\text { weight bearing deep knee bend using } \\
\text { fluoroscopy for five control patients } \\
\text { with a healthy knee, five patients with an } \\
\text { ACL-deficient knee, and } 20 \text { patients ( } 20 \\
\text { knees) who had a TKA with a posterior- } \\
\text { stabilized knee replacement designed for } \\
\text { deep flexion }\end{array}$ & $\begin{array}{l}\text { A low incidence of femoral condylar } \\
\text { liftoff was recorded in this study for } \\
\text { the patients implanted with TKA. } \\
\text { The average weight bearing ROM } \\
\text { (measured using fluoroscopy) for } \\
\text { patients with a knee replacement was } \\
125.0^{\circ} \text { similar kinematic patterns to } \\
\text { the control patients with a healthy } \\
\text { knee, and it can be hypothesized that } \\
\text { forces acting on the patella were not } \\
\text { increased substantially for the knee } \\
\text { replacement design analyzed when } \\
\text { compared with the control patients }\end{array}$ & & Favor \\
\hline
\end{tabular}

TKR: total knee replacement, TKA: total knee arthroplasty, DVT: deep vein thrombosis, ROM: range of motion, GA: general anaesthesia, ACL: anterior cruciate ligament. 
propriately selected patients. One of the disadvantages of the high flexion design is to increase patello-femoral and other stresses during deep degrees of flexion, which can also be overcome to some extent by using PFC Sigma Rotating Platform Knees (DePuy Orthopaedics Inc., Warsaw, IN, USA) knees with high conformity.

Functional results of high flexion designs to enable deep degrees of flexion are controversial and inconclusive, but they cannot be ignored. Several Level IV studies and a few Level II studies have shown significant improvement in flexion range of motion and patient's ability to squat, sit cross-legged, and kneel down with a good early and mid-term survivorship of the implant and very few complications. Maximum flexion of up to $155^{\circ}$ was reproduced and about $60 \%$ of the patients could do successful squatting and sitting cross-legged ${ }^{23-26)}$. These studies have not shown any incidences of condylar lift-off, cam-post disengagement or increases in the incidence of loosening. Studies have shown that high flexion design, despite less preoperative flexion, resulted in good postoperative flexion, significantly better than that after total knee replacement using the conventional knee prosthesis. The high flexion design successfully increased postoperative flexion by $15^{\circ}-25^{\circ}$ compared to the preoperative flexion. Studies have also proved that a satisfactory percentage of patients was able to squat, kneel, and sit cross-legged with high flexion knee prosthesis as compared to conventional knee prosthesis ${ }^{27,28)}$. There are few Level I and Level II studies that have shown no significant improvement in flexion after total knee replacement high flexion designs; as compared to the traditional posterior-stabilized design, only $2^{\circ}-5^{\circ}$ of improvement of flexion was observed and there was no difference with respect to the ability of flexion. These studies reported almost equal early- to mid-term survivorship of traditional and high flexion designs ${ }^{22,29-32)}$. As compared to the traditional posterior-stabilized design, high flexion designs exhibit better congruency between the polythene insert and the posterior condyles of the femoral component in beyond $90^{\circ}$ of flexion. This significantly decreases "Digging effect" caused by unequal and high stress distribution in deeper flexion when the traditional posterior stabilized design is in use ${ }^{33)}$. In our experience, high flexion knee prosthesis meets demands for obtaining higher degrees of flexion and performing activities like squatting, kneeling, and sitting cross-legged, although this cannot be solely attributable to implant design, and various other factors including patient selection, precise surgical technique, preoperative range of motion, body mass index, primary etiology of arthritis, preoperative deformity, etc. could play significant roles.

In our experience, high flexion prosthesis could be useful with proper patient selection and standard principles of total knee arthroplasty. The overall clinical results of total knee replacement using posterior-stabilized high flexion prosthesis are almost the same as those using traditional posterior stabilized design as proved by several Level I and Level II studies, but there are several confounding factors present in each study that need to be dealt with. So, the functional results of high flexion knee arthroplasty is good in certain groups of patients, but its usefulness in all patient populations needs to be evaluated further. There are no specific complications attributable to high flexion design except for the excess bone cut compared to traditional posterior stabilized designs. The long-term survivorship of this prosthesis is still in question, but it has good early- to mid-term survivorship.

We have some important observations and recommendations based on our experience of using 800 higher flexion knee prostheses. All high flexion designs are not the same and their kinematics is different. They can be either fixed-bearing or mobile-bearing. In addition, all fixed-or mobile-bearing cruciateretaining and cruciate-substituting designs are not the same. Functional and long-term results will vary due to this important reason. There are no uniform patient administered questionnaires being used in all studies and the knee society and other commonly used scoring systems do not address functional outcomes of the high flexion design. It is recommended that this disparity should be sorted out to obtain uniform functional results. There is definite concern for the amount of bone resected during high flexion knee arthroplasty, especially in Indian or Asian patients with small stature. Our recommendation is to use bone preserving and preferably cruciate-retaining high flexion designs. Posterior bone preserving designs will also help prevent damage to the posteromedial complex of the knee. We have described various studies for and against the high flexion design in Table 1.

High flexion total knee arthroplasty must be done with appropriate patient selection and precise surgical techniques to obtain successful outcomes. Future avenue using bone-preserving designs is going to be a key factor.

\section{Conflict of Interest}

No potential conflict of interest relevant to this article was reported.

\section{References}

1. Kurtz SM, Lau E, Ong K, Zhao K, Kelly M, Bozic KJ. Future young patient demand for primary and revision joint 
replacement: national projections from 2010 to 2030. Clin Orthop Relat Res. 2009;467:2606-12.

2. Ewald FC, Wright RJ, Poss R, Thomas WH, Mason MD, Sledge CB. Kinematic total knee arthroplasty: a 10- to 14year prospective follow-up review. J Arthroplasty. 1999;14: 473-80.

3. Callaghan JJ, Squire MW, Goetz DD, Sullivan PM, Johnston RC. Cemented rotating-platform total knee replacement. A nine to twelve-year follow-up study. J Bone Joint Surg Am. 2000;82:705-11.

4. Rowe PJ, Myles CM, Walker C, Nutton R. Knee joint kinematics in gait and other functional activities measured using flexible electrogoniometry: how much knee motion is sufficient for normal daily life? Gait Posture. 2000;12:143-55.

5. Mulholland SJ, Wyss UP. Activities of daily living in nonWestern cultures: range of motion requirements for hip and knee joint implants. Int J Rehabil Res. 2001;24:191-8.

6. Park KK, Chang CB, Kang YG, Seong SC, Kim TK. Correlation of maximum flexion with clinical outcome after total knee replacement in Asian patients. J Bone Joint Surg Br. 2007;89:604-8.

7. Ritter MA, Harty LD, Davis KE, Meding JB, Berend ME. Predicting range of motion after total knee arthroplasty. Clustering, log-linear regression, and regression tree analysis. J Bone Joint Surg Am. 2003;85:1278-85.

8. Anouchi YS, McShane M, Kelly F Jr, Elting J, Stiehl J. Range of motion in total knee replacement. Clin Orthop Relat Res. 1996;(331):87-92.

9. Schurman DJ, Rojer DE. Total knee arthroplasty: range of motion across five systems. Clin Orthop Relat Res. 2005; (430):132-7.

10. Dennis DA, Komistek RD, Scuderi GR, Zingde S. Factors affecting flexion after total knee arthroplasty. Clin Orthop Relat Res. 2007;464:53-60.

11. Sultan PG, Most E, Schule S, Li G, Rubash HE. Optimizing flexion after total knee arthroplasty: advances in prosthetic design. Clin Orthop Relat Res. 2003;(416):167-73.

12. Li G, Most E, Sultan PG, Schule S, Zayontz S, Park SE, Rubash HE. Knee kinematics with a high-flexion posterior stabilized total knee prosthesis: an in vitro robotic experimental investigation. J Bone Joint Surg Am. 2004;86:1721-9.

13. W-Dahl A, Robertsson O, Lidgren L. Surgery for knee osteoarthritis in younger patients. Acta Orthop. 2010;81:161-4.

14. Moynihan AL, Varadarajan KM, Hanson GR, Park SE, Nha KW, Suggs JF, Johnson T, Li G. In vivo knee kinematics during high flexion after a posterior-substituting total knee arthroplasty. Int Orthop. 2010;34:497-503.

15. Nakayama K, Matsuda S, Miura H, Iwamoto Y, Higaki H, Otsuka K. Contact stress at the post-cam mechanism in posterior-stabilised total knee arthroplasty. J Bone Joint Surg Br. 2005;87:483-8.

16. Ranawat CS. Design may be counterproductive for optimizing flexion after TKR. Clin Orthop Relat Res. 2003;(416): 174-6.

17. Nagura T, Dyrby CO, Alexander EJ, Andriacchi TP. Mechanical loads at the knee joint during deep flexion. J Orthop Res. 2002;20:881-6.

18. Sharma A, Komistek RD, Scuderi GR, Cates HE Jr. Highflexion TKA designs: what are their in vivo contact mechanics? Clin Orthop Relat Res. 2007;464:117-26.

19. Argenson JN, Komistek RD, Mahfouz M, Walker SA, Aubaniac JM, Dennis DA. A high flexion total knee arthroplasty design replicates healthy knee motion. Clin Orthop Relat Res. 2004;(428):174-9.

20. Bollars P, Luyckx JP, Innocenti B, Labey L, Victor J, Bellemans J. Femoral component loosening in high-flexion total knee replacement: an in vitro comparison of highflexion versus conventional designs. J Bone Joint Surg Br. 2011;93:1355-61.

21. Han HS, Kang SB, Yoon KS. High incidence of loosening of the femoral component in legacy posterior stabilised-flex total knee replacement. J Bone Joint Surg Br. 2007;89:1457-61.

22. Kim YH, Park JW, Kim JS. High-flexion total knee arthroplasty: survivorship and prevalence of osteolysis: results after a minimum of ten years of follow-up. J Bone Joint Surg Am. 2012;94:1378-84.

23. Maniar RN, Singhi T. High-flex rotating platform knee implants: two- to 6-year results of a prospective study. J Arthroplasty. 2012;27:598-603.

24. Weeden SH, Schmidt R. A randomized, prospective study of primary total knee components designed for increased flexion. J Arthroplasty. 2007;22:349-52.

25. Endres S, Wilke A. High flexion total knee arthroplasty: mid-term follow up of 5 years. Open Orthop J. 2011;5:13842.

26. Huang HT, Su JY, Wang GJ. The early results of high-flex total knee arthroplasty: a minimum of 2 years of follow-up. J Arthroplasty. 2005;20:674-9.

27. Meftah M, Ranawat AS, Ranawat CS. Safety and efficacy of a rotating-platform, high-flexion knee design three- to fiveyear follow-up. J Arthroplasty. 2012;27:201-6.

28. Gupta SK, Ranawat AS, Shah V, Zikria BA, Zikria JF, 
Ranawat CS. The P.F.C. sigma RP-F TKA designed for improved performance: a matched-pair study. Orthopedics. 2006;29(9 Suppl):S49-52.

29. Mehin R, Burnett RS, Brasher PM. Does the new generation of high-flex knee prostheses improve the post-operative range of movement?: a meta-analysis. J Bone Joint Surg Br. 2010;92:1429-34.

30. Murphy M, Journeaux S, Russell T. High-flexion total knee arthroplasty: a systematic review. Int Orthop. 2009;33:88793.

31. Sumino T, Gadikota HR, Varadarajan KM, Kwon YM, Rubash HE, Li G. Do high flexion posterior stabilised total knee arthroplasty designs increase knee flexion? A meta analysis. Int Orthop. 2011;35:1309-19.

32. McCalden RW, MacDonald SJ, Bourne RB, Marr JT. A randomized controlled trial comparing "high-flex" vs "standard" posterior cruciate substituting polyethylene tibial inserts in total knee arthroplasty. J Arthroplasty. 2009;24(6 Suppl):33-8.

33. Kelly MA. High-flexion knee designs: more hype than hope? In opposition. J Arthroplasty. 2006;21(4 Suppl 1):42-3.

34. Kim YH, Sohn KS, Kim JS. Range of motion of standard and high-flexion posterior stabilized total knee prostheses. A prospective, randomized study. J Bone Joint Surg Am. 2005;87:1470-5.

35. Nutton RW, van der Linden ML, Rowe PJ, Gaston P, Wade FA. A prospective randomised double-blind study of functional outcome and range of flexion following total knee replacement with the NexGen standard and high flexion components. J Bone Joint Surg Br. 2008;90:37-42.

36. Wohlrab D, Ditl J, Herrschelmann R, Schietsch U, Hein W, Hube R. Does the NexGen LPS flex mobile knee prosthesis offer advantages compared to the NexGen LPS?: a comparison of clinical and radiological results. Z Orthop Ihre Grenzgeb. 2005;143:567-72.

37. Sancheti KH, Laud NS, Bhende H, Reddy G, Pramod N, Mani JN. The INDUS knee prosthesis - Prospective multicentric trial of a posteriorly stabilized high-flex design: 2 years follow-up. Indian J Orthop. 2009;43:367-74.

38. Nutton RW, Wade FA, Coutts FJ, van der Linden ML. Does a mobile-bearing, high-flexion design increase knee flexion after total knee replacement? J Bone Joint Surg Br. 2012;94:1051-7.

39. Kim TH, Lee DH, Bin SI. The NexGen LPS-flex to the knee prosthesis at a minimum of three years. J Bone Joint Surg Br. 2008;90:1304-10.

40. Hepinstall MS, Ranawat AS, Ranawat CS. High-flexion total knee replacement: functional outcome at one year. HSS J. 2010;6:138-44.

41. Lee BS, Chung JW, Kim JM, Kim KA, Bin SI. High-flexion prosthesis improves function of TKA in Asian patients without decreasing early survivorship. Clin Orthop Relat Res. 2013;471:1504-11.

42. Nam SW, Lee YS, Kwak JH, Kim NK, Lee BK. A comparison of the clinical and radiographic results of press fit condylar rotating-platform high-flexion and low contact stress mobile bearing prosthesis in total knee arthroplasty: short term results. Knee Surg Relat Res. 2012;24:7-13. 